ORIGINAL ARTICLE

\title{
Deficiencies in Concussion Education in Canadian Medical Schools
}

\author{
Matthew J. Burke, Josie Chundamala, Charles H. Tator
}

\begin{abstract}
Background: Recent reports raise concern that physician knowledge of the identification and management of concussion may be deficient. There is little information known about the adequacy of concussion education provided to physicians or medical students. The present study assesses the concussion curriculum offered at medical schools in Canada. Methods: We asked all 17 Canadian medical schools to complete a questionnaire on their concussion curriculum, including the following: year of medical school offered; format/setting; and estimated teaching hours. The responses were organized into three categories: (1) concussion-specific education; (2) head injury education incorporating a concussion component; and (3) no concussion education. Results: Replies were received from $14(82 \%)$ of the 17 medical schools in Canada. Of the 14 responding schools, four (29\%) provided concussion-specific education, six (43\%) offered head injury education that incorporated a concussion component, and four (29\%) reported no concussion teaching in their curriculum. Conclusion: We found deficiencies in the concussion education curriculum provided in the majority of Canadian medical schools. To address this issue, we recommend that all medical schools should, at a minimum, include a one-hour formal concussion-specific teaching session in an early year of their curriculum to be followed by clinical exposure to concussed patients in the later years of medical school. Future studies will be necessary to evaluate if these recommended curricular enhancements are effective in remedying the reported gaps in physicians' concussion knowledge and whether the improved curriculum translates into better care for patients suffering concussion.
\end{abstract}

RÉSUMÉ: Lacunes dans l'enseignement dispensé dans les facultés de médecine au Canada sur la commotion cérébrale. Contexte : Des rapports récents soulèvent des inquiétudes au sujet de lacunes dans les connaissances des médecins concernant le diagnostic et la prise en charge de la commotion cérébrale. Il existe peu d'information à savoir si l'enseignement fait aux médecins et aux étudiants en médecine sur la commotion cérébrale est adéquat. Cette étude évalue le curriculum sur la commotion cérébrale offert dans les facultés de médecine au Canada. Méthode : Nous avons demandé aux 17 facultés de médecine canadiennes de compléter un questionnaire portant sur leur curriculum sur la commotion cérébrale, incluant celui de l'année suivante, le format/le cadre et le nombre d'heures d'enseignement. Les réponses ont été réparties en trois catégories : 1) enseignement portant spécifiquement sur la commotion cérébrale; 2) enseignement portant sur le traumatisme crânien incluant la commotion cérébrale et 3) aucun enseignement sur la commotion cérébrale. Résultats : Nous avons reçu des réponses de 14 des 17 facultés de médecine du Canada (82\%). Quatre des 14 facultés de médecine qui ont répondu (29\%) offraient un enseignement distinct sur la commotion cérébrale, 6 (43\%) offraient l'enseignement sur la commotion cérébrale dans le cadre de l'enseignement sur le traumatisme crânien et 4 (29\%) ont rapporté ne pas offrir d'enseignement sur la commotion cérébrale dans leur curriculum. Conclusion : Nous avons identifié des lacunes dans le curriculum concernant l'enseignement sur la commotion cérébrale offert dans la majorité des facultés de médecine au Canada. Pour résoudre ce problème, nous recommandons que toutes les facultés de médecine devraient à tout le moins inclure une session d'enseignement formel d'une heure portant spécifiquement sur la commotion cérébrale au début du curriculum suivi, dans les années subséquentes, d'expérience clinique auprès de patients ayant subi une commotion cérébrale. Si ces recommandations sont suivies, des études ultérieures portant sur leur efficacité à remédier aux lacunes rapportées dans les connaissances des médecins sur la commotion cérébrale et indiquant si un curriculum amélioré se traduit par de meilleurs soins offerts à ces patients devraient être effectuées.

Can J Neurol Sci. 2012; 39: 763-766

Concussion is currently an important public health issue in Canada. There are concerns about the knowledge-base of those involved with the diagnosis and management of concussions. Previous studies have identified deficiencies in the knowledge of concussion of coaches, athletic trainers and the general public. ${ }^{1-3}$ The present research focuses on the concussion education of medical students because physicians play a critical role in concussion diagnosis and management, including guidelines for return to play, work and/or school.

Recent studies and consensus panel statements suggest that physician knowledge of the identification and management of concussion is inadequate..$^{4-6}$ However, research into the reasons for such knowledge gaps is limited. For example, there is minimal information on the amount and type of concussion education provided in medical school, residency training or continuing medical education programs. There is only one publication evaluating the concussion curriculum of physicians in training. This study involved pediatric residency programs in the United States and concluded that sports medicine education, including the teaching of concussion management, was

From the University of Toronto, and Toronto Western Hospital, Toronto, Ontario, Canada.

Received March 28, 2012. Final Revisions Submitted June 14, 2012. Correspondence to: Charles H. Tator, University of Toronto, ThinkFirst Canada Toronto Western Hospital, 399 Bathurst St., Ste. 4W-433, Toronto, Ontario, M5T 2S8, Email: charles.tator@uhn.ca. 
deficient. ${ }^{7}$ It has been suggested that the medical school curriculum should be an important source of concussion education. ${ }^{8}$ No studies have evaluated the amount and type of concussion teaching in North American medical schools. The purpose of the present study was to assess the concussion curriculum at Canadian medical schools.

\section{Methods}

From April 2011 to February 2012, we contacted all 17 medical schools in Canada. Initially an email was sent to the Dean of Undergraduate Medical Education at each school. Subsequently, correspondence was via telephone and/or email with either the Dean or their designated medical education representative. We asked each school to complete a Concussion Education Questionnaire that consisted of a table with the following questions on concussion curriculum content for each year of medical school: "concussion education (Yes/No); if yes, what was the form of curriculum (lecture, seminar, problembased learning (PBL), etc.)?; If yes, estimated number of teaching hours?"

The collected curriculum information was summarized and organized into three categories: (1) concussion-specific education - session of one hour or more specifically dedicated to concussion; (2) head injury education incorporating a concussion component - session on a broader/related topic with some specific information or at least one learning objective on concussion; and (3) no concussion education.

\section{RESULTS}

Of the 17 medical schools contacted, 14 (82\%) replied. Four of the 14 medical schools $(29 \%)$ provided concussion-specific education (Category 1) as follows: one first-year PBL case; one second-year lecture; one third-year lecture; and one school with a series of three lectures (one in second year and two in fourthyear). Six schools $(43 \%)$ offered head injury education that incorporated a concussion component (Category 2). These sessions covered topics such as: sports medicine and traumatic brain injury. However, the exact duration or details pertaining to concussion education within these sessions could not be determined. Finally, four schools $(29 \%)$ reported that there was no concussion teaching in their curriculum. It should be noted that three of the four schools that provided Category 1 educational sessions offered Category 2 educational sessions as well. The Table and the Figure contain a more detailed description of the curriculum data collected from each medical school.

\section{DisCUSSION}

We showed that there is a marked deficiency in the concussion education curriculum provided in Canadian medical schools. Approximately $70 \%$ of schools surveyed had no concussion-specific curriculum of any form in any year of study. There are many possible explanations for these findings. First, the topic of concussion lies at the interface of many disciplines, including: emergency medicine, pediatrics, family medicine, sports medicine, neurology and neurosurgery. Thus, at the level of undergraduate medical education, concussion may have been overlooked because it was thought to be covered by another discipline. Second, many medical schools in Canada closely align their curriculum to the Medical Council of Canada (MCC) objectives for the MCC Qualifying Exam (MCCQE). ${ }^{9}$ We discovered that there are no MCCQE objectives that focus on concussion identification or management. Indeed, a search of the MCCQE objective database for "concussion", revealed two

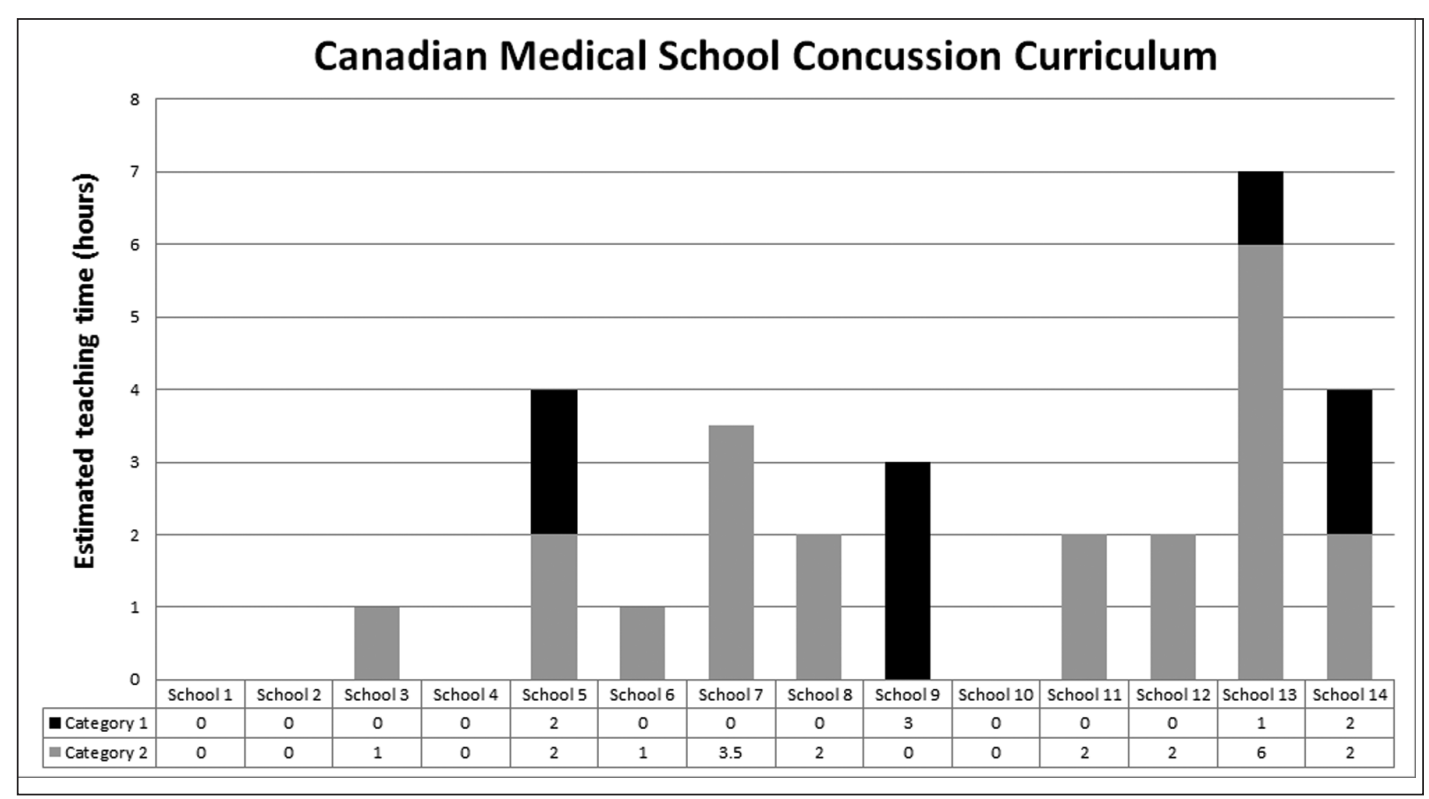

Figure: Category (1) = concussion-specific education; Category (2) = head injury education incorporating a concussion component 
Table: Summary of Canadian medical school concussion education curriculum

\begin{tabular}{|c|c|c|c|}
\hline \multirow[t]{2}{*}{$\begin{array}{l}\text { Medical } \\
\text { School }\end{array}$} & \multirow[t]{2}{*}{ Curriculum Description/Format } & \multicolumn{2}{|c|}{$\begin{array}{l}\text { Teaching hours } \\
\text { per Category }\end{array}$} \\
\hline & & (1) & (2) \\
\hline \multicolumn{4}{|l|}{ School 1} \\
\hline Years 1-4 & None & & \\
\hline \multicolumn{4}{|l|}{ School 2} \\
\hline Years 1-4 & None & & \\
\hline \multicolumn{4}{|l|}{ School 3} \\
\hline Years $1,3 \& 4$ & None & & \\
\hline Year 2 & Lecture on brain injury & & 1 \\
\hline \multicolumn{4}{|l|}{ School 4} \\
\hline Years 1-4 & None & & \\
\hline \multicolumn{4}{|l|}{ School 5} \\
\hline Years 2-4 & None & & \\
\hline Year 1 & $\begin{array}{l}\text { PBL on the presentation of acute head injury } \\
\text { PBL on concussions in sport }\end{array}$ & 2 & 2 \\
\hline \multicolumn{4}{|c|}{ (2: } \\
\hline Years $1,3 \& 4$ & None & & \\
\hline Year 2 & Lecture on disorders of consciousness & & 1 \\
\hline \multicolumn{4}{|l|}{ School 7} \\
\hline Years $1,2 \& 4$ & None & & \\
\hline Year 3 & Seminar on sports medicine (Family Medicine clerkship) & & 3.5 \\
\hline \multicolumn{4}{|c|}{ ( } \\
\hline Years $1,3 \& 4$ & None & & \\
\hline Year 2 & $\begin{array}{l}\text { Lecture on traumatic brain injury } \\
\text { Lecture on pediatric trauma }\end{array}$ & & 1 \\
\hline \multicolumn{4}{|l|}{ School 9} \\
\hline Years $1 \& 3$ & None & & \\
\hline Year 2 & Lecture on concussion & 1 & \\
\hline Year 4 & $\begin{array}{l}\text { Lecture on concussion (Emergency Medicine clerkship) } \\
\text { Lecture on concussion (Surgery clerkship) }\end{array}$ & 1 & \\
\hline \multicolumn{4}{|l|}{ School 10} \\
\hline Years 1-4 & None & & \\
\hline \multicolumn{4}{|l|}{ School 11} \\
\hline Years $1,3 \& 4$ & None & & \\
\hline Year 2 & Lecture on neurosurgery cases & & 2 \\
\hline \multicolumn{4}{|l|}{ School 12} \\
\hline Years 2-4 & None & & \\
\hline Year 1 & Lecture on sports medicine & & 2 \\
\hline \multicolumn{4}{|l|}{ School 13} \\
\hline Years $2 \& 4$ & None & & \\
\hline Year 1 & PBL on head trauma & & 6 \\
\hline Year 3 & Lecture on concussion (Surgery clerkship) & 1 & \\
\hline \multicolumn{4}{|l|}{ School 14} \\
\hline Years $1,3 \& 4$ & None & & \\
\hline Year 2 & $\begin{array}{l}\text { Lecture on concussion } \\
\text { PBL on head trauma }\end{array}$ & 2 & 2 \\
\hline
\end{tabular}

Category $(1)$ = concussion-specific education; Category $(2)=$ head injury education incorporating a concussion component; $\mathrm{PBL}=$ Problem-Based Learning 
results: (i) under "coma" - listed in brackets as "diffuse brain involvement - other", and (ii) under "head trauma/brain death/transplant donations" - discussed in "applicable basic principles of law" regarding capacity and informed decisionmaking of the concussed or intoxicated patient. Clearly, there are insufficient objectives regarding concussion in the MCCQE database.

Based on our findings, we strongly recommend inclusion of specific concussion education in the curriculum of Canadian medical schools. We believe that medical school is the ideal location for concussion education because patients with concussion present to a wide variety of primary care and specialist physicians. Provision of concussion education before career differentiation would be inclusive, efficient and practical. Further studies are necessary to determine the optimal content, format and duration of concussion education in the medical curriculum. However, until such information is available, we recommend the use of a comprehensive one-hour concussionspecific lecture that has been endorsed by the Concussion Education and Awareness Committee of ThinkFirst Canada and the Ontario Neurotrauma Foundation. This lecture was pilottested at the University of Toronto in 2011. It will be available for free online download at http://www.thinkfirst.ca and will be circulated to all Canadian medical schools. Ideally, the concussion teaching session should be followed by clinical exposure to concussion in the later years of medical school. Finally, we advocate that the MCC develop enhanced specific learning objective(s) on concussion that include both identification and management.

Our conclusions are limited by the survey design of this study. Though we informed the schools that all collected data would remain anonymous, responses were not received from three schools. This could be a source of non-response bias. In addition, the accuracy of the information gathered from schools that did respond, relied on the knowledge and curriculum searching/analysis techniques employed by the corresponding Dean or education representative. Curricular information provided may have been incomplete or inaccurate.

Concussions are now properly recognized as brain injuries with serious potential consequences, and require an adequate place in the curriculum of all medical schools. The current deficiencies in concussion education in medical schools require correction. Future studies should evaluate if implementation of the recommended enhanced teaching is effective in filling the reported gaps in physicians' concussion knowledge and whether an improved curriculum translates into better care for patients suffering concussion.

\section{FUNDING}

This research study was supported by funding from the Ontario Neurotrauma Foundation.

\section{ACKNOWLEDGEMENTS}

The authors thank Dr. Jay Rosenfield, Dean of Undergraduate Medical Education at the University of Toronto, for his assistance with contacting the Deans of Undergraduate Medical Education at the Canadian medical schools.

\section{REFERENCES}

1. Cusimano M. Canadian minor hockey participants' knowledge about concussion. Can J Neurol Sci. 2009;36(3):315-20.

2. Guilmette T, Malia L, Mcguiggan M. Concussion understanding and management among New England high school football coaches. Brain Inj. 2007;21(10):1039-47.

3. Covassin T, Elbin R, Stiller-Ostrowski JL. Current sport-related concussion teaching and clinical practices of sports medicine professionals. J Athl Train. 2009;44(4):400-4

4. McCrory P, Meeuwisse W, Johnston K, et al. Consensus statement on concussion in sport 3rd international conference on concussion in sport held in Zurich, November 2008. Clin J Sport Med. 2009;19:185-200.

5. Colantonio A, Saverino C, Zagorski B, et al. Hospitalizations and emergency department visits for TBI in Ontario. Can J Neurol Sci. 2010;37(6):783-90.

6. Boggild $\mathrm{M}$, Tator $\mathrm{CH}$. Concussion knowledge among medical students and neurology/neurosurgery residents. Can J Neurol Sci. 2012;39(3):361-8.

7. Demorest RA, Bernhardt DT, Best TM, et al. Pediatric residency education: is sports medicine getting its fair share? Pediatrics. 2005; 115:28-33.

8. Provvidenza CF, Johnston KM. Knowledge transfer principles as applied to sport concussion education. Br J Sports Med. 2009;43 (Suppl I):i68-i75.

9. Medical Council of Canada. Objectives for the qualifying examination, 3rd edition. [cited 2011 Dec 12] Available from: http://www.mcc.ca/Objectives_Online/objectives.pl?loc=home \&lang=english. 